\title{
Therapy with antisense TGF- $\beta 1$ oligodeoxynucleotides reduces kidney weight and matrix mRNAs in diabetic mice
}

\author{
DONG CHEOL HAN, BRENDA B. HOFFMAN, SOON WON HONG, \\ JIA GUO, AND FUAD N. ZIYADEH \\ Renal-Electrolyte and Hypertension Division and Penn Center for Molecular \\ Studies of Kidney Diseases, Department of Medicine, University of Pennsylvania \\ School of Medicine, Philadelphia, Pennsylvania 19104-6144
}

\begin{abstract}
Han, Dong Cheol, Brenda B. Hoffman, Soon Won Hong, J ia Guo, and Fuad N. Ziyadeh. Therapy with antisense TGF- $\beta 1$ oligodeoxynucleotides reduces kidney weight and matrix mRNAs in diabetic mice. Am J Physiol Renal Physiol 278: F628-F634, 2000.-Inhibition of gene expression by antisense oligodeoxynucleotides (ODNs) relies on their ability to bind complementary mRNA sequences and prevent translation. The proximal tubule is a suitable target for ODN therapy in vivo because circulating ODNs accumulate in the proximal tubule in high concentrations. Because increased proximal tubular transforming growth factor- $\beta 1$ (TGF- $\beta 1$ ) expression may mediate diabetic renal hypertrophy, we investigated the effects of antisense TGF- $\beta 1$ ODN on the high-glucose-induced proximal tubular epithelial cell hypertrophy in tissue culture and on diabetic renal hypertrophy in vivo. Mouse proximal tubular cells grown in $25 \mathrm{mM}$ D-glucose and exposed to sense ODN as control $(1 \mu \mathrm{M})$ exhibited increased ${ }^{3}[\mathrm{H}]$ leucine incorporation by $120 \%$ and total TGF- $\beta 1$ protein by $50 \%$ vs. culture in $5.5 \mathrm{mM}$ D-glucose. Antisense ODN significantly decreased the high-glucose stimulated TGF - $\beta 1$ secretion and leucine incorporation. Continuous infusion for 10 days of ODN (100 $\mu \mathrm{g} /$ day) was achieved via osmotic minipumps in diabetic and nondiabetic mice. Sense ODN-treated streptozotocin-diabetic mice had $15.3 \%$ increase in kidney weight, $70 \%$ increase in $\alpha 1$ (IV) collagen and $46 \%$ increase in fibronectin mRNA levels compared with nondiabetic mice. Treatment of diabetic mice with antisense ODN partially but significantly decreased kidney TGF- $\beta 1$ protein levels and attenuated the increase in kidney weight and the $\alpha 1$ (IV) collagen and fibronectin mRNAs. In conclusion, therapy with antisense TGF- $\beta 1$ ODN decreases TGF- $\beta 1$ production and attenuates high-glucose-induced proximal tubular cell hypertrophy in vitro and partially prevents the increase in kidney weight and extracellular matrix expression in diabetic mice.
\end{abstract}

transforming growth factor- $\beta 1$; nephropathy; proximal tubule; glucose; collagen type IV; fibronectin; osmotic minipumps

DIABETIC RENAL HYPERTROPHY is a consistent finding in the early stage of type 1 diabetes mellitus in humans and in the streptozotocin-diabetes model $(23,25)$. Increased steady-state mRNA levels encoding type IV

The costs of publication of this article were defrayed in part by the payment of page charges. The article must therefore be hereby marked "advertisement" in accordance with 18 U.S.C. Section 1734 solely to indicate this fact. collagen and fibronectin in the kidney are also features of the early stages of diabetic nephropathy $(9,14,22)$. Diabetic renal hypertrophy is predominantly due to tubular epithelial cell hypertrophy, which accounts for the increase in whole kidney weight $(16,19,20)$. Hyperglycemia and other metabolic and hemodynamic factors underlying the diabetic state are the principal causes for the development of diabetic nephromegaly $(19,25)$. In fact, recent in vitro studies provided evidence that high ambient glucose per se can induce proximal tubular epithelial cell hypertrophy $(29,33$, 34) and increase the synthesis of extracellular matrix components in these cells $(3,34)$.

Several key pieces of evidence have implicated the TGF- $\beta$ system as an etiologic agent in the genesis and maintenance of diabetic renal hypertrophy $(11,30)$. In an in vitro system, we have previously reported that proximal tubular epithelial cells express significant increments in TGF- $\beta 1$ mRNA levels and bioactivity when cultured in high glucose concentration (17). Furthermore, we and others have demonstrated that TGF- $\beta 1$ mRNA and protein levels are significantly increased in the kidney cortex after only a few days of overt hyperglycemia in animal models of type 1 diabetes mellitus $(14,21,24)$. Direct evidence implicating the TGF- $\beta$ system in the pathogenesis of experimental diabetic renal hypertrophy has derived from the results of a short-term study whereby a neutralizing monoclonal antibody directed against all three mammalian isoforms of TGF $-\beta$ was administered intraperitoneally to streptozotocin-diabetic mice (22). Treatment with the anti body totally prevented gl omerular hypertrophy, reduced the increment in kidney weight by $\sim 50 \%$, and significantly attenuated the increase in renal mRNA levels of $\alpha 1$ (IV) collagen and fibronectin. However, the individual contribution of the TGF- $\beta 1$ isoform al one in mediating the renohypertrophic effects of the diabetic state could not be deciphered from these studies.

Recent advancements in biotechnology have made possible the application of antisense oligodeoxynucleotide (ODN) therapy in vivo to inhibit the function of a specific protein or enzyme $(4-6,27)$. Inhibition of gene expression by antisense ODNs relies on their ability to bind complementary mRNA sequences and the prevention of protein translation (26). The proximal tubule is a suitable target for ODN therapy in vivo because it has been previously demonstrated that circulating ODNs 
accumulate in the kidney, mainly in the proximal tubule, in concentrations that are higher than in any other organ $(6,18,31)$. F or example, therapy with antisense ODN s against the sodium-phosphate cotransporter suppressed phosphate uptake into the brushborder membrane of the proximal tubule (13). Because increased proximal tubular TGF- $\beta 1$ expression may mediate diabetic renal hypertrophy, we investigated the effects of therapy with antisense TGF- $\beta 1$ ODN on the high-glucose-stimulated protein synthesis in proximal tubular cell culture and on diabetic renal hypertrophy in vivo. This allowed us to test the hypothesis that increased activity of the renal TGF- $\beta 1$ system in early diabetes mellitus in mice contributes to renal hypertrophy in this disease.

\section{METHODS}

Proximal tubular cell culture. MCT is a murine proximal tubular cell line that has been propagated in culture by SV-40 virus transformation (7). The cells demonstrate stable structural and functional features that are characteristic of differentiated proximal tubular epithelial cells $(7,28)$. Cells were cultured at $37^{\circ} \mathrm{C}$ in a humidified incubator with $5 \% \mathrm{CO}_{2}-95 \%$ air and passaged twice every week by light trypsinization. The growth media was DMEM (GIBCO-BRL) containing 5.5 $\mathrm{mM}$ D-glucose, $10 \% \mathrm{FCS}, 100 \mathrm{U} / \mathrm{ml}$ penicillin, $100 \mu \mathrm{g} / \mathrm{ml}$ streptomycin, and $2 \mathrm{mM}$ glutamine.

Preparation of ODNs. We designed and synthesized 19-mer ODNs that were phosphorothioate modified to increase stability (Cancer Center, Univ. of Pennsylvania). The antisense ODN encompasses the ATG of the murine TGF $-\beta 1$ gene and has the sequence 5'-AGGGCGGCATGGGGGAGGC-3' (6.13 $\mathrm{mg} / \mu \mathrm{mol})$. The sense ODN, used as control, has the sequence 5'-GCCTCCCCCATGCCGCCCT-3' $(5.75 \mathrm{mg} / \mu \mathrm{mol})$. Lyophilized ODNs were resuspended in distilled water and then diluted to give the required final concentration.

${ }^{3}[\mathrm{H}]$ ] leucineincorporation. I ncorporation of $3[\mathrm{H}]$ leucine into acid-precipitable proteins was used as a sensitive index of de novo protein synthesis in MCT cells $(29,33,34)$. Cells were plated at $5 \times 10^{5}$ cells/well in 24-well plates (Nunc) in the growth media. The next day, cells were rested in serum-free medium for $24 \mathrm{~h}$ and then exposed for $48 \mathrm{~h}$ to either normal $(5.5 \mathrm{mM})$ or high $(25 \mathrm{mM}) \mathrm{D}$-glucose. Sense or antisense ODN s $(1 \mu \mathrm{M})$ were added to some of the wells. For the last $12 \mathrm{~h}$ of culture, cells were pulsed with $5 \mu \mathrm{Ci}{ }^{3}[\mathrm{H}]$ leucine $(142 \mathrm{Ci} /$ $\mathrm{mmol}$, Amersham). Cell monolayers were washed twice with ice-cold phosphate-buffered saline, precipitated in ice-cold $10 \%$ TCA, redissolved in $500 \mu \mathrm{l}$ of $0.5 \mathrm{M} \mathrm{NaOH}+0.1 \%$ Triton $\mathrm{X}-100$, and counted for $\beta$ emissions. Additional plates of cells exposed to the same experimental conditions were used to obtain cell counts in a Coulter counter. Leucine incorporation was expressed as counts per minute per $10^{6}$ cells.

Diabetic mice. Diabetes was induced in 8-wk-old C57/bl female mice by two consecutive intraperitoneal injections of streptozotocin (200 mg $\mathrm{kg}^{-1}$. day ${ }^{-1}$; Sigma Chemical) dissolved in $10 \mathrm{mM} \mathrm{Na}$ citrate, pH 5.5 (22). Nondiabetic mice were injected with buffer alone. Once glycosuria was detected, regular insulin (0.1-0.2 U) was administered subcutaneously every day to prevent ketonuria and maintain a moderately el evated blood glucose concentration (22-28 mM). Osmotic minipumps (model 2002, Alza) were implanted subcutaneously in the flank of each mouse under sterile conditions. The next day, diabetic and nondiabetic mice were weight-matched to receive either sense or antisense ODNs. The ODN delivery rate through the pump was $100 \mu \mathrm{g} /$ day. At the end of the experimental period, individual 24-h urine collections were obtained. The animals were then weighed, blood was collected, and the kidneys wereharvested, weighed, and immediately frozen in liquid nitrogen for RNA and protein extraction. Kidney protein extracts were determined in duplicate (Bio-Rad).

TGF- $\beta 1$ ELISA. Total (latent + active) TGF $-\beta 1$ levels were measured in MCT-conditioned culture media, mouse plasma, urine, and kidney protein extracts by using an ELISA kit (Genzyme), as previously described $(8,22)$. Quiescent MCT cells were cultured as described above. Cells were exposed for $48 \mathrm{~h}$ to DMEM containing either 5.5 or $25 \mathrm{mM}$ D-glucose and incubated in the presence of sense or antisense TGF- $\beta 1$ ODNs. At the end of the incubation period conditioned media were collected, centrifuged, and stored in $-70^{\circ} \mathrm{C}$. Samples of media, plasma, or urine were acid activated to convert latent into active TGF - $\beta 1$ and to record detectable levels of TGF - $\beta 1$. Samples were activated with $1 \mathrm{~N} \mathrm{HCl}$ for $60 \mathrm{~min}$ at $4^{\circ} \mathrm{C}$ followed by neutralization with $1 \mathrm{~N} \mathrm{NaOH}$. Samples were plated on microtiter plates coated with mouse monoclonal anti-human TGF- $\beta 1$ antibody and incubated at $37^{\circ} \mathrm{C}$ for 60 min. After being washed fivetimes, wells were incubated with a second horseradish peroxidase-conjugated polyclonal antiTGF- $\beta 1$ antibody, and then the peroxidase reaction was initiated. A standard curve was constructed by using serial dilutions of human TGF- $\beta 1$ (Genzyme), and TGF- $\beta 1$ levels in samples were compared with known standards and read as nanograms per $10^{6} \mathrm{cells}$. TGF - $\beta 1$ levels in urine samples were expressed per milligram of urinary creatinine, measured by a colorimetric assay (Sigma Chemical). Total kidney levels of TGF- $\beta 1$ protein were expressed per milligram protein of tissue extract.

Northern hybridization. Cultured MCT cells or frozen kidneys were lysed and denatured in $4 \mathrm{M}$ guanidinium thiocyanate, $25 \mathrm{mM}$ sodium citrate, $\mathrm{pH} 7.0,0.5 \%$ sarcosyl, and $0.1 \mathrm{M}$ 2-mercaptoethanol $(24,32)$. RNA extraction was performed as previously described. RNA from individual samples $(25 \mu \mathrm{g})$ were el ectrophoresed on a $1.2 \%$ agarose gel containing $0.67 \mathrm{M}$ formaldehyde, transferred by capillary blotting to Gene-Screen nylon membrane (NEN Research Products), and ultraviolet crosslinked. The cDNA probes encoding murine $\alpha 1$ (IV) collagen, fibronectin, and ribosomal protein mrpL 32 were as previously reported $(12,22)$. Hybridization and washing were performed as previously described $(8,32)$. The membranes were autoradiographed with intensifying screens (Kodak, Wilmington, DE) at $-70^{\circ} \mathrm{C}$ for $1-4$ days. Exposed films were scanned with a laser densitometer (Hoefer Scientific I nstruments), and mRNA levels were calculated relative to corresponding $\mathrm{mrpL} 32$. Measurements of density in normal glucose media (5.5 $\mathrm{mM})$ or in nondiabetic mice treated with sense ODN were assigned a relative value of $100 \%$.

Statistical analysis. Data are presented as the means $\pm \mathrm{SE}$ with $\mathrm{n}$ as the number of different experiments or the number of animals per group. Groups were compared by analysis of variance, and an unpaired t-test was used to compare individual groups. A P value $<0.05$ was considered significant.

\section{RESULTS}

Response of proximal tubular cells. Total TGF- $\beta 1$ protein was measured by ELISA to test whether antisense TGF- $\beta 1$ ODN was able to reduce TGF- $\beta 1$ synthesis in MCT cells. As control, exposure of MCT cells to high ambient glucose concentration $(25 \mathrm{mM})$ for $48 \mathrm{~h}$ without treatment with ODN, stimulated total TGF- $\beta 1$ protein secretion into the culture media by $\sim 50 \%$ 
compared with normal glucose concentration (5.5 mM) (Fig. 1). Addition of $1 \mu \mathrm{M}$ antisense TGF- $\beta 1$ ODN effectively reduced the high-glucose-induced increase in TGF- $\beta 1$ (Fig. 1). However, and as would be expected, there was no inhibitory effect on TGF- $\beta 1$ production when MCT cells were exposed to sense ODN (Fig. 1).

We previously reported that high glucose inhibits proximal tubular cell proliferation but induces hypertrophy (34). Neutralizing anti-TGF- $\beta$ antibodies directed against TGF $-\beta 1$ and TGF $-\beta 2$ prevented the antiproliferative effect of high glucose (17). To demonstrate that the hypertrophic effect of high ambient glucose is mediated by increased activity of the TGF $-\beta 1$ system in these cells, we tested whether antisense TGF- $\beta 1$ ODN is capable of reducing the high-glucose-stimulated leucine incorporation. Figure 2 shows that MCT cells without or with supplemental sense ODN displayed a $>2.2$-fold increase in leucine incorporation when cultured in high glucose for $48 \mathrm{~h}$. However, the highglucose-stimulated incorporation was significantly attenuated when antisense ODN $(1 \mu \mathrm{M})$ was added to the media (Fig. 2). In addition, antisense ODN (1 $\mu \mathrm{M})$ reduced the high-glucose-stimulated fibronectin mRNA (relative to $\mathrm{mrpL}$ 32) 1.8-fold to 1.3-fold, compared with normal glucose media $(n=3, P<0.05)$. These results suggest that autocrine production of TGF $-\beta 1$ is respon-

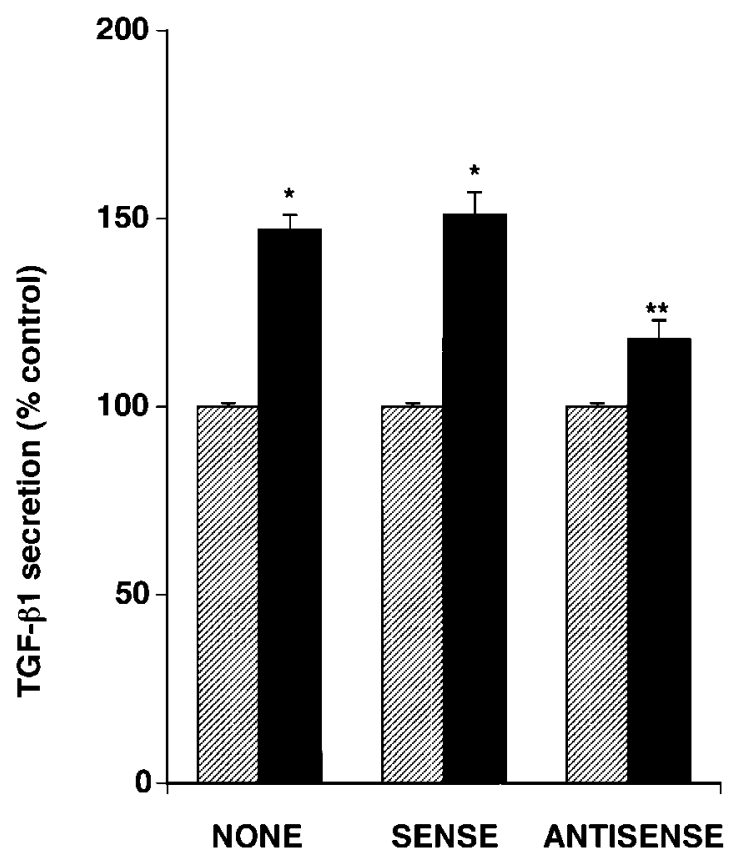

Fig. 1. Effect of oligodeoxynucleotides on transforming growth factor- $\beta 1$ (TGF- $\beta 1$ ) production. Confluent MCT cells were made quiescent for $24 \mathrm{~h}$ and then studied for an additional $48 \mathrm{~h}$ in serum-free DMEM containing either 5.5 or $25 \mathrm{mM}$ D-glucose, with or without addition of senseand antisense TGF- $\beta 1$ oligodeoxynucleotides (ODNs). ELISA for total TGF- $\beta 1$ protein secretion (latent + active) was performed on conditioned media and was expressed per total cell protein content. Normal glucose (hatched bar); high glucose (filled bars). Values are means \pm SE. Cells grown in high glucose demonstrate a significant increase in total TGF- $\beta 1$ secretion compared with cells grown in normal glucose $(* \mathrm{P}<0.01$ vs. corresponding normal glucose; $n=6$ ). This increase in TGF- $\beta 1$ by high glucose was partially diminished by antisense TGF $-\beta 1$ ODNs (** $\mathrm{P}<0.05$ vs. high glucose alone or sense-treated cells grown in high glucose).

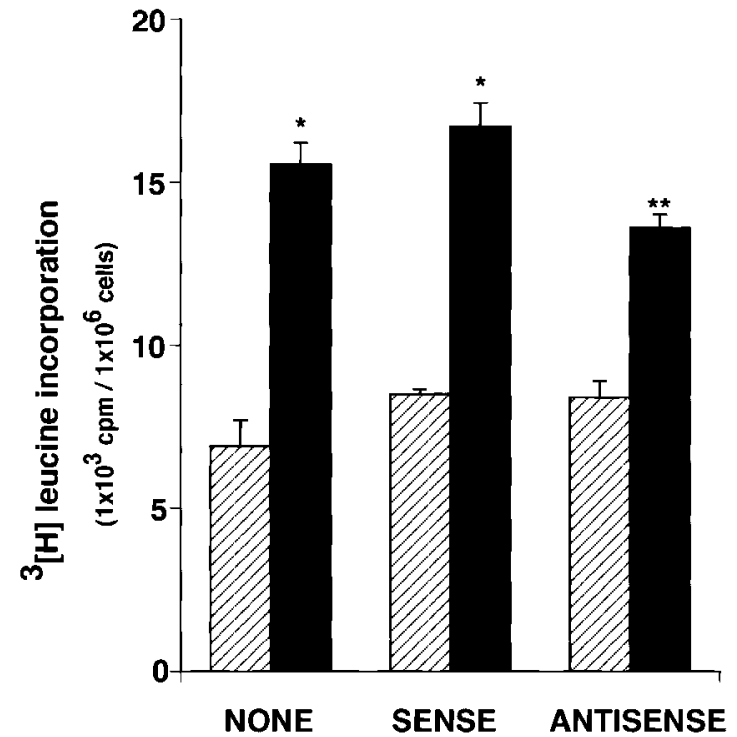

Fig. 2. Effect of ODN on ${ }^{3}[\mathrm{H}]$ leucine incorporation. Confluent MCT cells were made quiescent for $24 \mathrm{~h}$ and then studied for an additional $48 \mathrm{~h}$ in serum-free DMEM containing either 5.5 or $25 \mathrm{mM}$ D-glucose, with or without addition of sense and antisense TGF- $\beta 1$ ODN. Normal glucose (hatched bars); high glucose (filled bars). Leucine incorporation was expressed as counts $\cdot \mathrm{min}^{-1} \cdot 10^{6}$ cells. Values are for means $\pm \mathrm{SE}$. High glucose significantly stimulated ${ }^{3}[\mathrm{H}]$ leucine incorporation compared with normal glucose. However, treatment with antisense TGF- $\beta 1$ ODNs partially diminished this stimulation compared with high glucoseal one or sense-treated cells. $* P<0.01$ vs. normal glucose. $* * \mathrm{P}<0.05$ vs. high glucose alone or sense-treated cells grown in high glucose; $\mathrm{n}=6$.

sible, at least in part, for the stimulatory effect of high glucose on protein synthesis and matrix expression in MCT cells. It is also possible that the high-glucosestimulated protein synthesis and matrix expression could be mediated partly by other isoforms of TGF- $\beta$ and/or by non-TGF- $\beta$ pathways.

Response of diabetic hypertrophy. Table 1 displays the body and kidney weights and the blood glucose concentration after 10 days of ODN infusion in the four groups of mice. Diabetic mice treated with either sense or antisense ODNs had equivalently elevated blood glucose concentration at the end of the study period (Table 1). Body weight was similarly reduced in the diabetic mice treated with either sense or antisense ODNs. N one of the animals died during the study. Total kidney weight increased by $15.3 \%$ in diabetic mice

Table 1. Profile of body and kidney weights and blood glucose in normal and diabetic micetreated with sense or antisenseTGF- $\beta 1$ ol igodeoxynucl eotides for 10 days

\begin{tabular}{ccclc}
\hline \hline Mice & $\mathrm{n}$ & $\begin{array}{c}\text { Body } \\
\text { Wt, } \mathrm{g}\end{array}$ & $\begin{array}{c}\text { Kidney } \\
\text { Wt, mg }\end{array}$ & $\begin{array}{c}\text { Blood } \\
\text { Glucose, } \mathrm{mM}\end{array}$ \\
\hline $\begin{array}{c}\text { Nondiabetic } \\
\text { Sense }\end{array}$ & 8 & $20.1 \pm 0.4$ & $240 \pm 7$ & $7.5 \pm 0.2$ \\
Antisense & 8 & $20.2 \pm 0.2$ & $246 \pm 3$ & $7.3 \pm 0.4$ \\
Diabetic & & & & \\
Sense & 8 & $17.9 \pm 0.3^{*}$ & $276 \pm 14^{*}$ & $25.7 \pm 2.3^{*}$ \\
Antisense & 8 & $18.0 \pm 0.3^{*}$ & $262 \pm 7^{*}+$ & $25.6 \pm 2.1^{*}$ \\
\hline
\end{tabular}

Values are means \pm SE. TGF, transforming growth factor. $* \mathrm{P}<$ 0.05 vs. nondiabetic. $† P<0.05$ vs. sense-diabetic. 
treated with senseTGF- $\beta 1$ ODN compared with nondiabetic control mice $(240 \pm 7$ vs. $276 \pm 14 \mathrm{mg}$, respectively, $\mathrm{P}<0.05)$. In contrast, kidney weight in diabetic mice treated with antisense TGF- $\beta 1$ ODN was increased by $6.5 \%$ only, compared with antisense ODNtreated nondiabetic mice (Table 1). Thus the increment in total kidney weight in antisense ODN-treated diabetic mice was less than one-half that of sense ODNtreated diabetic mice. These results suggest that autocrine production of TGF- $\beta 1$ is responsible, at least in part, for the acute stimulatory effect of diabetes on kidney weight in mice.

Light microscopy of the kidneys derived from the different groups of mice revealed no pathological lesions in the different compartments (cortical interstitial, glomerular, and vascular), and there were no changes induced by the treatment with the oligonucleotides. Tubular cell height appeared increased in the kidney of diabetic mice compared with the normal kidney but, there were no other perceptible changes because the duration of the diabetic state was only 10 days.

Response of therenal TGF - $\beta 1$ system in diabetic mice. Plasma levels of TGF- $\beta 1$ were not significantly different between the normal and diabetic groups, suggesting that the short duration of the diabetic state did not increase circulating TGF - $\beta 1$ (data not shown), confirming our previous report (22). In contrast, urinary levels of total TGF- $\beta 1$ protein (latent + active fractions) were markedly stimulated in diabetic mice (sense ODNtreated diabetic mice: $6.7 \pm 1.3 \mathrm{ng} / \mathrm{mg}$ creatinine vs. sense ODN-treated nondiabetic controls: $1.1 \pm 0.3$ $\mathrm{ng} / \mathrm{mg}$ creatinine; $\mathrm{P}<0.05)$. Treatment of diabetic mice with antisense ODN reduced urinary TGF- $\beta 1$ levels only slightly and not significantly $(5.9 \pm 1.2 \mathrm{ng} / \mathrm{mg}$ creatinine). However, Fig. 3 demonstrates that the markedly elevated TGF- $\beta 1$ protein level in the kidney extracts of diabetic mice was significantly attenuated by treatment with antisense ODN (Fig. 3; 29\% reduction in the increment of renal TGF- $\beta 1$ protein compared with sense ODN-treated diabetic mice). These studies are consistent with the notion that the diabetic state is characterized by increased renal production of TGF- $\beta 1$ and that systemic administration of antisense TGF- $\beta 1$ ODN is effective in attenuating this increment.

Response of matrix overexpression in diabetic kidney. Figure $4, A$ and $B$, shows that the MRNA encoding $\alpha$ I(IV) collagen in the kidney of diabetic mice treated with sense ODN was increased by $70 \%$ compared with sense ODN-treated nondiabetic mice after 10 days of diabetes. Inhibition of renal TGF- $\beta 1$ with antisense ODN treatment was associated with significantly decreased overexpression of $\alpha \mathrm{I}(\mathrm{IV})$ collagen mRNA; the increment was only $24 \%$ in antisense ODN-treated mice compared with sense ODN-treated mice (Fig. 4, A and $\mathrm{B}$ ). Figure 5, A and B, demonstrates similar changes in renal fibronectin mRNA expression; the $46 \%$ increase in mRNA level in sense-treated diabetic mice was significantly reduced by antisense ODN treatment, nearly to the level found in nondiabetic mice treated with sense ODN. Thus inhibiting TGF- $\beta 1$ activity in

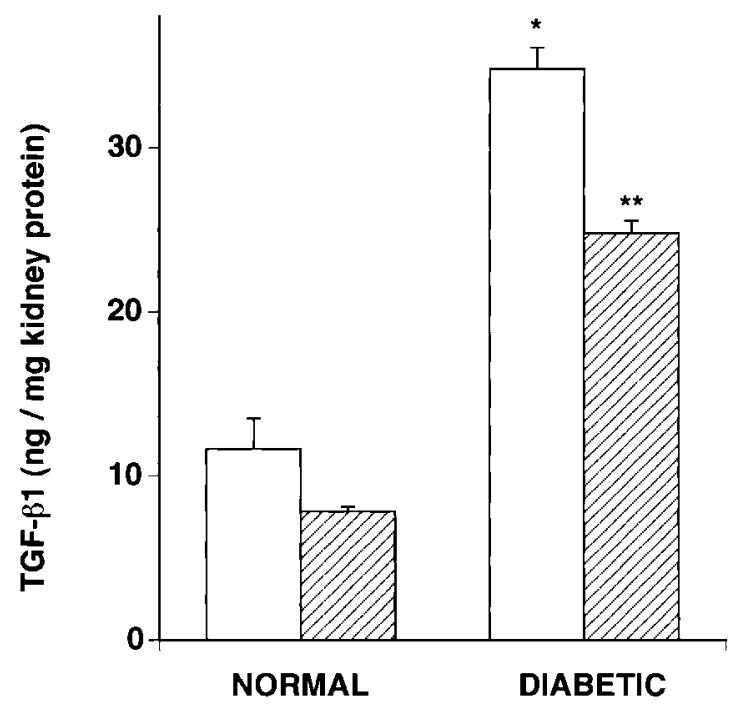

Fig. 3. Effect of ODN on TGF- $\beta 1$ protein in kidney extract. Nondiabetic control mice and streptozotocin-diabetic mice were infused with either sense (open bars) or antisense ODN (hatched bars) for 10 days via osmotic minipumps. ELISA for total TGF- $\beta 1$ protein content (latent + active) was performed on kidney extracts and was expressed per total kidney protein content. Values are means $\pm \mathrm{SE}$. Note that the increase in renal TGF $-\beta 1$ protein in diabetic mice $(* \mathrm{P}<$ 0.01 vs. nondiabetic mice, $n=8$ ), was partially suppressed by anti-sense TGF- $\beta 1$ ODN (**P $<0.05$ vs. sense-treated diabetic mice; $n=8)$.

the early phase of streptozotocin-induced diabetes markedly attenuates the stimulation in gene expression of the extracellular matrix molecules, type IV collagen and fibronectin, in the mouse kidney. However, we cannot exclude that other isoforms of TGF- $\beta$ and/or non-TGF- $\beta$ pathways can be partly responsible for increased matrix expression in the kidney.

\section{DISCUSSION}

Increased activity of the renal TGF- $\beta$ system has been implicated as an etiol ogic factor in the genesis and maintenance of diabetic renal hypertrophy (22). We sought to test this hypothesis by examining the effects of therapy with antisense TGF- $\beta 1$ ODN on the highglucose-mediated tubular epithelial cell hypertrophy in vitro and on diabetic renal hypertrophy in vivo. Antisense ODN suppressed the high-glucose-stimulated TGF- $\beta 1$ secretion and leucine incorporation in mouse renal proximal tubular cells in culture. Short-term continuous infusion of antisense ODN in streptozotocininduced diabetic mice significantly decreased renal TGF- $\beta 1$ protein levels and attenuated the increase in kidney weight and extracel lular matrix mRNA levels.

Our previous investigations in tissue culture have shown that high glucose concentration in the culture media of proximal tubule cells inhibits cell proliferation $(33,34)$, induces cell hypertrophy $(29,34)$, and increases TGF- $\beta 1$ mRNA level and bioactivity (17). High glucose concentration also stimulates collagen gene transcription and secretion $(33,34)$. A neutralizing anti-TGF $-\beta$ antibody that is directed against TGF- $\beta 1$ and TGF- $\beta 2$ prevents the inhibitory effect of high glucose on cell proliferation (17). Using specific anti- 
A

\section{Mouse Kidney}

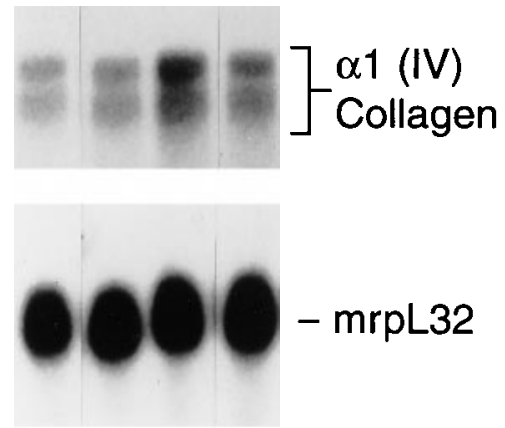

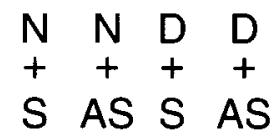

B

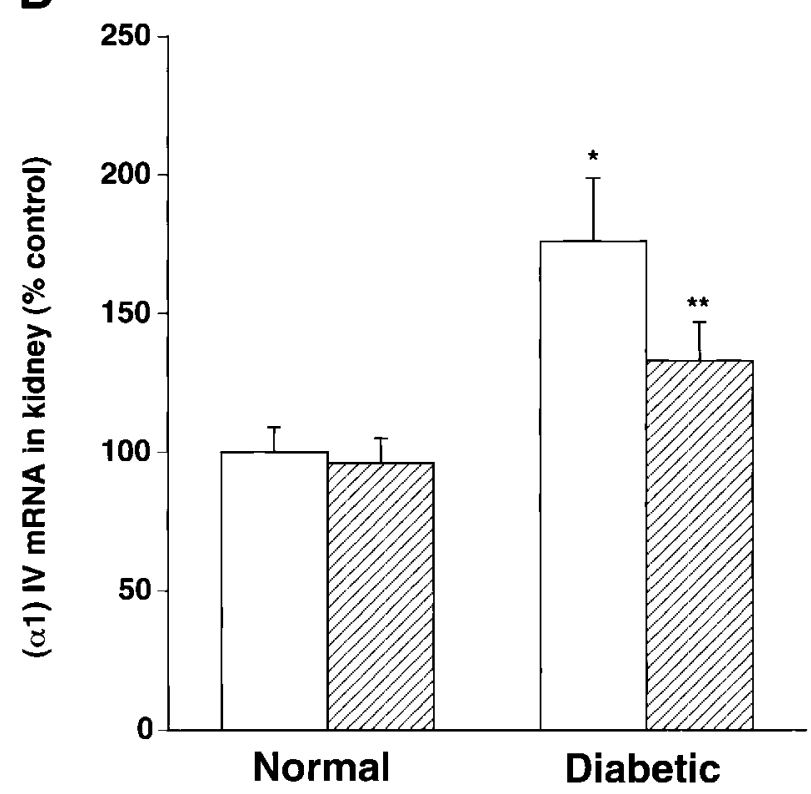

Fig. 4. Effects of ODN on renal collagen type IV gene expression. Nondiabetic control mice (N) and streptozotocin-diabetic (D) mice were infused with either sense (S, open bars) or antisense ODN (AS; hatched bars) for 10 days via osmotic minipumps. A: representative Northern blot of kidney RNA probed with CDNA encoding murine $\alpha 1$ (IV) (top) and mrpL 32 as control (bottom). B: summary of densitometric analysis of ratios for $\alpha 1$ (IV)/mrpL 32 mRNA levels in 4 treatment groups. Values are means $\pm \mathrm{SE}$. Note that the increase in renal $\alpha 1$ (IV) mRNA in diabetic mice ( ${ }^{*} \mathrm{P}<0.01$ vs. nondiabetic mice; $\mathrm{n}=8$ ) was partially suppressed by antisense TGF- $\beta 1$ ODN (**P $<$ 0.05 vs. sense-treated diabetic mice; $n=8$ ).

sense TGF- $\beta 1$ ODN in the present study, we demonstrate that autocrine production of TGF $-\beta 1$ is responsible, at least in part, for the stimulatory effect of high glucose on protein synthesis and matrix expression in proximal tubular cells. Our studies in tubular cells extend the results of $\mathrm{Kolm}$ et al. (10), who used antisense TGF- $\beta 1$ ODN in cultured glomerular mesangial cells to inhibit the high-glucose-mediated stimulation of fibronectin and heparan sulfate proteoglycan production.

The experiments utilizing systemic infusion of antisense TGF- $\beta 1$ ODN in diabetic mice are the first to exploit this technique. The tissue distribution after administration of ODN through subcutaneous, intradermal, or intraperitoneal routes, is similar to that of intravenous injections (1). We administered ODN through a single subcutaneous implantation of miniosmotic pumps in mice to release ODNs over a 10-day period. The ODNs were phosphorothioate modified to increase stability and to prevent rapid degradation. The results of these experiments provide direct evi-

A

\section{Mouse Kidney}

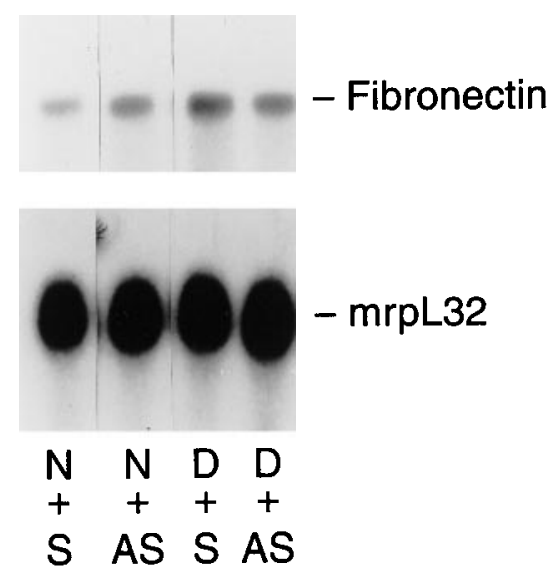

B

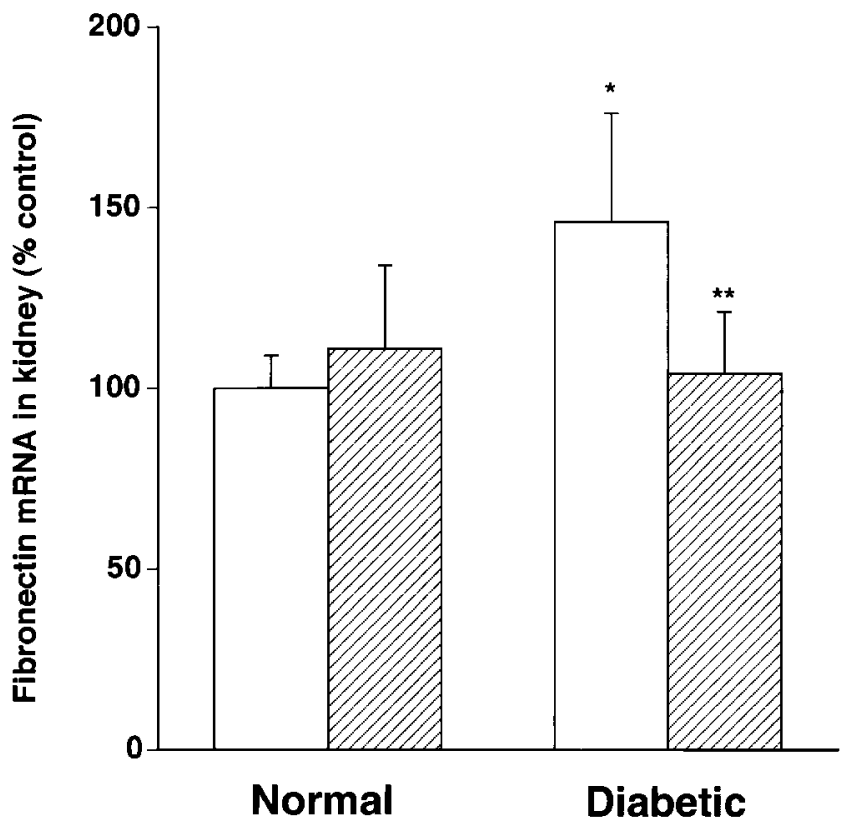

Fig. 5. Effects of ODN on renal fibronectin gene expression. Nondiabetic control mice (N) and streptozotocin-diabetic (D) mice were infused with either sense (S; open bars) or antisense ODN (AS; hatched bars) for 10 days via osmotic minipumps. A: representative Northern blot of kidney RNA probed with CDNA encoding murine fibronectin (top) and mrpL32 as control (bottom). B: summary of densitometric analysis of ratios for fibronectin/mrpL $32 \mathrm{mRNA}$ levels in the 4 treatment groups. Values are means $\pm \mathrm{SE}$. Note that the increase in renal fibronectin $\mathrm{mRNA}$ in diabetic mice $(* \mathrm{P}<0.01 \mathrm{vs}$. nondiabetic mice; $n=8$ ) was virtually prevented by antisense TGF $-\beta 1$ ODN (**P $<0.05$ vs. sense-treated diabetic mice; $n=8$ ). 
dence implicating TGF- $\beta 1$ specifically in the pathogenesis of diabetic renal hypertrophy. The increment in total kidney weight in antisense ODN-treated diabetic mice was only one-half that of sense ODN-treated diabetic mice. Additionally, treatment of diabetic mice with antisense ODN partially but significantly decreased kidney TGF- $\beta 1$ protein levels and attenuated the increase in the mRNA levels encoding $\alpha 1$ (IV) collagen and fibronectin in the kidney. Thus it can be concluded that the increased production of TGF- $\beta 1$ in the diabetic kidney is responsible, at least in part, for the acute stimulatory effect of the diabetic state on renal hypertrophy and the accompanying overexpression of extracellular matrix proteins. The persistently el evated urinary TGF- $\beta 1$ levels, despite antisense ODN treatment (as opposed to the significant decrement in total kidney TGF- $\beta 1$ levels), may relate to the possibility that urinary TGF- $\beta 1$ originates from multiple sources (the circulation, glomeruli, tubules), whereas ODN therapy targets effectively only tubules.

In a previous short-term in vivo study we demonstrated that intraperitoneal administration of a neutralizing monoclonal antibody directed against the three mammalian isoforms of TGF $-\beta$ (TGF $-\beta 1$, TGF $-\beta 2$, and TGF- $\beta 3$ ) into streptozotocin-diabetic mice prevented glomerular hypertrophy, reduced the increment in kidney weight, and significantly attenuated the increase in renal mRNA levels of $\alpha 1$ (IV) collagen and fibronectin (22). It was unclear what the contribution was of each of the three isoforms to the diabetic changes in the kidney (22). U sing specific reagents such as antisense ODN directed at the TGF- $\beta 1$ sequence, as was done in the present study, has provided evidence that increased production of TGF- $\beta 1$ in the diabetic kidney is responsible, at least in large part, for mediating diabetic renal hypertrophy.

The present study supports the feasibility and the efficacy of delivering specific ODNs to the kidney. Inhibition of gene expression by antisense ODN relies on its ability to bind complementary mRNA sequences and prevent translation $(4-6,27)$. The proximal tubule is a suitable target for ODN therapy in vivo because circulating ODNs accumulate in the kidney, mainly in the proximal tubule, in significantly high concentrations $(6,18,31)$. Because increased proximal tubular TGF- $\beta 1$ expression may mediate diabetic renal hypertrophy, systemic infusions of ODN are expected to accumulate in the proximal tubule where they can target TGF- $\beta 1$ production. U sing intravenous administration of ${ }^{32} \mathrm{P}$-labeled ODN , Rappaport et al. (15) readily detected the presence of ODN in Bowman's space, the proximal tubular lumen, and tubular epithelial cells where the ODN accumulated. In addition, Oberbauer et al. (13) demonstrated that antisense ODN directed at the sodium-phosphate cotransporter suppressed phosphate uptake across the brush-border membrane in the proximal tubule. Targeting other cells of the kidney may require different delivery systems. Gene transfer of TGF- $\beta 1$ antisense ODN to the glomerulus has been previously attempted by the hemagglutinating virus of J apan liposome method delivered through the arterial supply of the kidney (2); a successful reduction of matrix molecule overexpression in the glomerulus was therefore achieved in a model of glomerulonephritis. Targeting TGF- $\beta 1$ production in the glomerulus rather than the tubules in the diabetic state may require a similar approach as that used by Akagi and co-workers (2).

The partial effects of antisense ODN observed in this study may have many explanations, including the relatively low dose (which should avoid nonspecific effects), the role of other isoforms of TGF- $\beta$ and/or non-TGF- $\beta$ pathways in mediating diabetic hypertrophy, and the nonhomogeneous distribution of ODN in the kidney, which preferentially favors tubular uptake.

In conclusion, antisense TGF- $\beta 1$ ODN attenuates the high-glucose-induced hypertrophy of proximal tubular cells in vitro. In addition, short-term treatment with antisense TGF $-\beta 1$ ODN given in continuous infusion via osmotic minipumps is efficacious in decreasing renal TGF - $\beta 1$ production and attenuating kidney hypertrophy and the increase in extracellular matrix expression in diabetic mice.

This study was supported in part by National Institute of Diabetes and Digestive and Kidney Diseases Grants DK-44513, DK-45191, DK-54608, and training grant DK-07006 and the J uvenile Diabetes Foundation I nternational. Drs. D. C. Han and S. W. Hong are visiting scholars at the University of Pennsylvania. Dr. D. C. Han is supported by the Korean Research Foundation and the Hyonam Kidney Laboratory at Soon Chun Hyang University Hospital, Seoul, Korea. Dr. S. W. Hong is supported by Konsei University, Seoul, Korea. Dr. B. B. Hoffman is supported by an Individual National Research ServiceAward from the National I nstitutes of Health.

Address for reprint requests and other correspondence: F. N Ziyadeh, Renal-Electrolyteand Hypertension Division, Univ. of Pennsylvania, 700 Clinical Research Bldg., 415 Curie Blvd., Philadel phia, PA 19104-6144 (E-mail: ziyadeh@mail.med.upenn.edu).

Received 26 April 1999; accepted in final form 24 November 1999.

\section{REFERENCES}

1. Agrawal S. Antisense oligonucleotide: towards clinical trials. TIBTECH 14: 376-387, 1996.

2. Akagi Y, Isaka Y, Arai M, Kaneko T, Takenaka M, Moriyama T, Kaneda Y, Ando A, Orita Y, Kamada T, Ueda N, and Imai E. Inhibition of TGF $-\beta 1$ expression by antisense ol igonucleotides suppressed extracellular matrix in experimental glomerulone phritis. Kidney Int 50: 148- 155, 1996.

3. Bleyer A, Fumo P, Snipes ER, Goldfarb S, Simmons DA, and Ziyadeh FN. Polyol pathway mediates high glucoseinduced collagen synthesis in proximal tubule. Kidney Int 45: 659-666, 1994

4. Bunnell BA, Askari F K, and Wilson J M. Targeted delivery of antisense oligonucleotides by molecular conjugates. Somatic Cell Mol Genet 18: 559-569, 1992.

5. Dean NM and McKay R. Inhibition of protein kinase C- $\alpha$ expression in mice after systemic administration of phosphorothioate antisense oligodeoxynuceotides. Proc Natl Acad Sci USA 91: 11762-11766, 1994.

6. Hanss B, Rappaport J, Bruggeman L, Coffman T, and Klotman P. Kidney serves as a critical organ for the handling of systemic antisense for gene therapy. Clin Res 42: 221, 1994.

7. Haverty T, Kelly CJ, Hines WH, Amenta PS, Watanabe M, Harper RA, Kefalides NA, and Neilson E G. Characterization of a renal tubular epithelial cell line which secretes the autologous target antigen of autoimmune experimental interstitial nephritis. J Cell Biol 107: 1359-1368, 1988.

8. Hoffman BB, Sharma K, Zhu Y, and Ziyadeh F N. Transcriptional activation of TGF- $\beta 1$ in mesangial cell culture by high glucose concentration. Kidney I nt 54: 1107-1116, 1998. 
9. I hm C, Lee G, Nast C, Artishevsky A, Guillermo R, Levin R, Glassock R, and Adler S. Early increased procollagen $\alpha \mathbf{I}(\mathrm{IV})$ mRNA levels in streptozotocin induced diabetes. Kidney Int 41: 768-777, 1992.

10. Kolm V, Sauer U, Olgemoller B, and Schleicher ED. High glucose-induced TGF- $\beta 1$ regulates mesangial production of heparan sulfate proteoglycan. Am J Physiol Renal Fluid Electrolyte Physiol 270: F812-F821, 1996.

11. Mogyorosi A and Ziyadeh FN. U pdate on pathogenesis, markers, and management of diabetic nephropathy. Curr Opin Nephrol Hypertens 5: 243-253, 1996.

12. Mogyorosi A and Ziyadeh FN. Increased decorin mRNA in diabetic mouse kidney and in mesangial and tubular cells cultured in high glucose. Am J Physiol Renal Physiol. 275: F827-F 832, 1998.

13. Oberbauer R, Schreiner GF, Biber J , Murer H, and Meyer TW. In vivo suppression of the renal $\mathrm{Na}^{+} / \mathrm{Pi}$ cotransporter by antisense oligonucleotides. Proc Natl Acad Sci USA 93: 49034906, 1996.

14. Park I-S, Kiyomoto H, Abboud S, and Abboud H. Expression of transforming growth factor- $\beta$ and type IV collagen in early streptozotocin-induced diabetes. Diabetes 46: 473-480, 1997.

15. Rappaport J, Hanss B, Kopp J B, Copeland TD, Bruggeman LA, Coffman TM, and Klotman PE. Transport of phosphorothioate oligonucleotides in kidney: implications for molecular therapy. Kidney I nt 47: 1462- 1469, 1995.

16. Rasch R. Tubular lesions in streptozotocin diabetic rats. Diabe tologia 27: 32-37, 1984

17. Rocco M, Chen Y, Goldfarb S, and Ziyadeh FN. Elevated glucose stimulates TGF- $\beta$ gene expression and bioactivity in proximal tubule. Kidney Int 41: 107-114, 1992.

18. Sawai K, Miyao T, Takakura Y, and Hashida M. Renal disposition characteristics of oligonucleotides modified at terminal linkages in the perfused rat kidney. Antisense Res Dev 5: 270-287, 1995.

19. Seyer-Hansen K. Renal hypertrophy in experimental diabetes mellitus. Kidney Int 23: 643-646, 1983.

20. Seyer-Hansen K, Hansen J, and Gunderson HJ G. Renal hypertrophy in experimental diabetes. A morphometric study. Diabetologia 18: 501-505, 1980.

21. Shankland SJ and Scholey J W. Expression of transforming growth factor- $\beta 1$ during diabetic renal hypertrophy. Kidney Int 46: 430-442, 1994.

22. Sharma K, Guo J , J in Y, and Ziyadeh F N. Neutralization of TGF $-\beta$ by anti-TGF- $\beta$ antibody attenuates kidney hypertrophy and the enhanced extracellular matrix gene expression in STZinduced diabetic mice. Diabetes 45: 522-530, 1996.

23. Sharma K, Han DC, Mogyorosi A, and Ziyadeh F N. Structural and functional consequences of streptozotocin-induced diabetes on the kidney. In: Experimental Models of Diabetes, edited by McNeill J H. Boca Raton, FL: CRC, 1999, p. 39-62.

24. Sharma $\mathbf{K}$ and Ziyadeh $\mathbf{F N}$. Renal hypertrophy is associated with upregulation of TGF- $\beta 1$ gene expression in diabetic BB rat and NOD mouse. Am J Physiol Renal Fluid Electrolyte Physiol 267: F 1094-F 1101, 1994.

25. Tuttle KR, Bruton J L, Perusek MC, Lancaster J L, Kopp DT, and DeF ronzo RA. Effect of strict glycemic control on renal hemodynamic response to amino acids and renal enlargement in insulin-dependent diabetes mellitus. N Engl J Med 324: 16261632,1991

26. Wagner RW. Gene inhibition using antisense ol igodeoxynucleotides. Nature 372: 333- 335, 1994.

27. Wang H, Watkins $\mathbf{C}$, and Malbon CC. Antisense oligodeoxynucl eotides to G-s protein a-subunit sequence accel erate differentation of fibroblasts to adi pocytes. Nature 358: 334- 337, 1992.

28. Wolf $\mathbf{G}$ and Neilson E G. Angiotensin II induces hypertrophy in cultured murine proximal tubular cells. Am J Physiol Renal Fluid Electrolyte Physiol 259: F 768-F 777, 1990.

29. Wolf G, Neilson EG, Goldfarb S, and Ziyadeh FN. The influence of glucose concentration on angiotensin II-induced hypertrophy of proximal tubular cells in culture. Biochem Biophys Res Commun 176: 902-909, 1991.

30. Wolf $\mathbf{G}$ and Ziyadeh $\mathbf{F N}$. The role of angiotensin II in diabetic nephropathy: emphasis on nonhemodynamic mechanisms. Am J Kidney Dis 29: 153- 163, 1997

31. Zhang R, Diasio RB, Lu Z, Liu T, J iang Z, Galbraith WM, and Agrawal S. Pharmacokinetics and tissue distribution in rats of an oligodeoxynucleotide phosphorothioate (GEM 91) developed as a therapeutic agent for human immunodeficiency virus type-1. Biochem Pharmacol 49: 929-939, 1995.

32. Ziyadeh FN, Sharma K, Ericksen M, and Wolf G. Stimulation of collagen gene expression and protein synthesis in murine mesangial cells by high glucose is mediated by activation of transforming growth factor- $\beta$. J Clin I nvest 93: 536-542, 1994.

33. Ziyadeh FN, Simmons DA, Snipes ER, and Goldfarb S. Effect of myo-inositol on cell proliferation and collagen transcription and secretion in proximal tubule cells cultured in elevated glucose. J Am Soc Nephrol 1: 1220-1229, 1991.

34. Ziyadeh FN, Snipes E R, Watanabe M, Alvarez RJ , Goldfarb S, and Haverty TP. High glucose induces cell hypertrophy and stimulates collagen gene transcription in proximal tubule. Am J Physiol Renal Fluid ElectrolytePhysiol 259: F 704-F 714, 1990. 